Original Research Article

\title{
Economics of catfish hatchery farmers and its contribution to household poverty alleviation in Nigeria
}

\author{
Samuel Segun Ashley-Dejo ${ }^{1}$, Olusunmbo Adeolu Adelaja ${ }^{2}$ \\ ${ }^{1}$ Department of Fisheries and Aquaculture, Federal University Gashua, Nigeria \\ ${ }^{2}$ School of Economics, Finance and Banking, Universiti Utara, Malaysia \\ Correspondence to: \\ S. S. Ashley-Dejo, Department of Fisheries and Aquaculture, Federal University Gashua, Nigeria; \\ e-mail: ashleydejosamuel@gmail.com
}

\begin{abstract}
Fish and fisheries products are considered as one of the most substantial parts of Nigeria economy. Demand for these products is on the high side due to the rapid growth of human population, changes in lifestyle and eating habits. Fishery is thus serving as a source of employment, income generation and food security. This paper made use of the data gathered from the farm and household levels to analyse the economics of catfish hatchery farming and its contribution to household poverty alleviation in Oyo and Osun States, Southwest Nigeria, using profitability analyses, Foster-Greer-Thorbecke index and Tobit regression models. The findings indicate that fish hatchery farming is profitable, altough $43.1 \%$ of fish hatchery farmers interviewed were above the poverty line. Thus, the enterprise significantly $(p<0.05)$ reduced poverty in the study area. Furthermore, the effects of socioeconomic variables, gender, education level, and framing experience $(p<0.01)$; marital status and household size $(p<0.1)$; labour employed, hatchery units, quality of fish seed produced and membership of cooperative society $(p<0.05)$ indicating several interactions between poverty and the variables analysed. In conclusion, policy makers, government and non-governmental organisation should give the enterprise adequate attention and support as this could be adopted in lifting the country from poverty.
\end{abstract}

Keywords: Fish hatchery, profitability, poverty and determinants, Oyo and Osun States.

\section{INTRODUCTION}

Nigeria is blessed with a large expanse of water bodies consisting of marine and freshwaters which is about 900 kilometres and over 14 million hectares, respectively. Out of which $75 \%$ of freshwater is suitable for fish farming (Adelaja et al., 2018). This has made Nigeria to become the largest producer of fish and fisheries products in Saharan Africa and currently second to Egypt in Africa (Bolorunduro, 2016). Fish and fisheries products are considered as the most substantial part of food security and nutrition for many poor inhabitants in Low-Income Food Deficit Countries (LIFDC's) (Tesfay and Teferi, 2017). However, some inhabitants of LIFDCs depend on fish as the main source of micronutrients, minerals and essential fatty acids (Food and Agricultural Organization (FAO), 2020). In 2017, fish consumption per capita in Nigeria rose to $13.3 \mathrm{~kg}$, although it is below the world's average of $20.5 \mathrm{~kg}$ (FAO, 2018). With this, fish production in Nigeria is not on the same level as the rapid population growth of about 200 million with a projection of above 260 million by 2030 (Adelaja et al., 2018). Thus, there exists a great deficit of fish production in the country and the inability of this industry to meet up with the supply of fish consumed annually has been narrowed down to the fast-growing human population (Adelaja et al., 2018).

\section{(C) AUTHORS 2022}

This work is licensed under the Creative Commons Attribution-NonCommercial-NoDerivs 4.0 License (https://creativecommons.org/licenses/by-nc-nd/4.0/) 
On a global level, fish farming has been recognised as an important sector of agriculture in the fight against food security, malnutrition and in poverty eradication especially in LIFDC's (FAO, 2020). Fish farming has been proved to supply the much needed digestible and cheapest sources of animal protein and provision of other essential nutrients with very low cholesterol contents (Adelaja et al., 2018). These advantages have made fish farming to be among the world fastest growing food production sectors (Adelaja et al., 2018).

Fish farming was introduced to Nigeria about six decades ago by missionaries to combat malnutrition in pregnant women which yielded a positive result; the outcome prompted the Federal Government of Nigeria to establish different experimental stations (Ashley-Dejo, 2016). In Nigeria, fish farming, especially catfish production has been embraced by many regardless of age and educational qualification (Inoin et al., 2017). The enterprise has been reported to be viable (Ashley-Dejo et al., 2017), but the viability depends on factors such as fish seed, feed, feeding methods and technical know-how. Digun-Aweto and Oladele (2017) reported that for about a decade ago majority of fish hatchery in Nigeria target catfish production because it is the most consumed fish species. Thus, fish hatchery enterprise is gaining more popularity in its quest of meeting up with farmers' demand for fish seed. Several studies have been conducted on fish production in Nigeria, most especially on economic analysis, income generation and poverty alleviation, profitability analysis of fish farming. Although all these studies have contributed greatly to the economics of fish production in Nigeria, there still exists a literature gap in fish hatchery production which is the backbone of fish farming.

This study analysed the economics of fish hatchery farmers and its contribution to household poverty alleviation in Oyo and Osun States, Southwest Nigeria. The specific objectives are to identify different fish hatchery management systems; determine the profitability of fish hatchery enterprise; examine smallholder fish management systems; estimate the poverty status among fish hatchery farmers, and ascertain the contribution of fish hatchery enterprise to household poverty alleviation.

\section{Conceptual framework}

\section{Poverty}

Poverty is a multifaceted entity encompassing the inability to meet up with the basic need of individuals. It is also the failure or lack of revenue to meet up with essential survival needs. It is a state of having little or no money and denial of the chances of living long and healthy (Sidi, 2008). Poverty goes beyond qualitative observational analysis whether the individuals are privileged to have healthy and creative lives (Sidi, 2008).

Foster et al. (1984) developed the Poverty Count Index (PCI) and Household Expenditure (HE), respectively, which is often adopted in measuring poverty level. Lipton (1996) submitted that measuring poverty level using HE concentrates majorly on the living standard of households and attempts to differentiate between the poor and those that are not by matching their household budget. Households with higher expenditure are generally considered richer to their counterparts with lower expenditure. Invariable expenditure budget line refers to minimum expenditure figure and any household whose budgeted expenditure is above this figure is regarded as rich and vice versa (Ravallion, 1992). This approach was found to be inadequate because it gives higher poverty figure to rural dwellers whose revenue is lower compared with urban dwellers, therefore another measure was introduced, called PCI - Poverty Count Index. This is three-pronged measures that classify individuals into different poverty levels using poverty-gap index (Boltvinik, 1994). This approach uses the mean aggregate of individuals whose consumption is below the defined first poverty layer (Ravallion and Sen, 1994). Poverty is said to be predominant at the layer. The second measure in the square poverty-gap index which is based on a proportionate consumption shortfall (Ravillion and Sen, 1994). The third is the headcount index which is based on the assumption of the proportion of individual living in a household with average consumption lower than the poverty line. This approach is said to be the simplest and easiest measurement for poverty index.

\section{Poverty determinants}

Several scholars have carried out studies on poverty determinants among farming households using multiverse analysis (Igbalajobi et al., 2013; Ndamu, 2016), non-significant differences in factors mitigating against poverty among farming households were observed. Etuk et al. (2015) observed that poverty incidence and poverty gap was 0.569 and 0.48, respectively, among fish vendor households in Cross River State, Nigeria. In Africa, Nigeria inclusive. Poverty among farming households is said to be driven by three factors which are socio-economic, asset and institutional characteristics of the farmers (Etim and Patrick, 2010). Several studies have reported that possession of assets and affordable healthcare services alongside with farming input helps in reducing 
poverty among farming households (Ndamu, 2016; and Etuk et al., 2015). On socio-economic characteristics, it was observed that age, household size, farming experience and labour help in reducing poverty among farmer's households (Oladimeji et al., 2013). Also, Igbalajobi et al. (2013) reported negative association between poverty and gender, marital status, educational qualification, income, pond size and membership of cooperative society.

\section{MATERIALS AND METHODS}

\section{The study area}

The study areas are Oyo and Osun States which are located in the southwest of Nigeria. The states lie between $2^{\circ} 38.66^{\prime} \mathrm{N}$ and $4^{\circ} 38.325^{\prime} \mathrm{N}$ longitude and latitude $9^{\circ} 8.74^{\prime} \mathrm{E}$ and $7^{\circ} 1.68^{\prime} \mathrm{E}$ (Oyo State) and latitude $8^{\circ} 3.66^{\prime} \mathrm{E}$ and $7^{\circ} 0.25^{\prime} \mathrm{E}$ and longitude $4^{\circ} 1.52^{\prime} \mathrm{N}$ and $5^{\circ} 3.26^{\prime} \mathrm{N}$ (Osun State). The states share boundaries with Ogun State in the south, Kwara State in the north, the Republic of Benin in the west and in the east, it is bounded by Ekiti and Ondo States, respectively.

\section{Sampling procedure and sample size}

A multi-stage sampling procedure was adopted for this study which includes purposive and random sampling techniques. Oyo and Osun States were purposively selected due to consistent increase in aquaculture production in the states (National Agricultural Extension and Research Liaison Services (NAERLS) and National Programme on Agriculture and Food Security (NPAFS), 2010). Also, 20 Local Government Areas (LGA) each were purposively selected as follows: Ido, Akinyele, Egbeda, Ibarapa central, Ibarapa south west, Ibarapa east, Iseyin, Olorunogo, Ona-ara, Orire (Oyo state) Ayedaade, Boluwaduro, Ede north, Ede south, Ejigo, Ife north, Ife east, Ifelodun, Ila, Ilesa west (Osun State). Eleven (11) fish hatchery farmers were randomly selected from each LGA, the choice of selected LGAs was guided by extension agents. A total of 440 fish hatchery farmers were randomly selected and interviewed by trained enumerators within the months of June to September, 2018. However, 17 questionnaires were discarded due to inadequate information and thus data from 423 questionnaires were used for this study.

\section{Analytical techniques}

For this study, descriptive statistics, profitability analyses, Foster-Greer-Thorbecke index (Foster et al., 1984) and Tobit regression model were employed.

\section{Profitability analysis}

Fish hatchery profitability was analysed using the procedure described by Oluwatayo and Adedeji, (2019). The mathematical expression of the procedure employed as defined in Equation 1-5:

Gross Margin (GM) of fish hatchery enterprise =

$=$ Total Renevue - Total Variable Cost

Net Income (NI) of fish hatchery enterprise = $=$ Gross Margin - Total Fixed

Benefit - Cost Ratio (BCR) of fish hatchery

enterprise $=\frac{\text { Total Revenue }}{\text { Total Cost }}$

Returns on Investment (ROI) of fish hatchery

enterprise $=\frac{\text { Net Income }}{\text { Total Cost }}$

Depreciation was calculated for the fixed items to get their depreciated price which was incorporated in the calculation. Straight Line Method (SLM) was used for calculation of depreciation, which anticipated salvage value of zero.

Annual depreciation $=$

$\frac{\text { (Original Cost - Salvage Value) }}{\text { Expected or useful life span(years) }}$

\section{Poverty measurement}

Poverty profile of fish hatchery farmers was ascertained using weighted poverty index as described by Foster et al. (1984). The choice of this index is that it is a well-known index using quantitative poverty assessment. Foster-Greer-Thorbecke (FGT) measure is specified in Equation 6-8 and entails the quantification of households with expenditure below the poverty line. The poverty line is the value of revenue and consumption expenditure required for the minimum standard of living. For this study, the standard of living of fish hatchery farmers was measured based on food and non-food items (energy, outfit (clothing), hospital bill, transportation cost and social activities) which was summed up to arrive at the total households' expenditures. This was later divided using the number of each household's members to arrive at capital expenditure, as described by World Bank (1996). Capital expenditure was converted to adult expenditure as regards the age, gender and nutrition requirement of members of each household. This was achieved by adopting nutrition-based adult equivalent scales 
Table 1. Description of poverty determinants among fish hatchery farmers

\begin{tabular}{llc}
\hline Variables & Description & Unit \\
\hline Gender & Dummy variable: $(1=$ male, $0=$ female $)$ & Dummy \\
Age & Fish hatchery farmers age & Years \\
Marital status & Dummy variable: $(1=$ married, $0=$ single $)$ & Dummy \\
Household size & Number of fish hatchery farmer family & Number \\
Educational level & Educational qualification of fish hatchery farmer & Years \\
Farming experience & Years of fish hatchery enterprise & Year \\
Labour employed & Number of manpower & Man-days \\
Hatchery units & Number of hatchery units & Number \\
Value of assets & Price of fish hatchery farmer asset & Naira (N) \\
Quantity of fish seed produced & Price of fish seed produced per breeding season & Naira (N) \\
Access to modern health care & Dummy variable: $(1=$ access, $0=$ non-access $)$ & Dummy \\
Membership of cooperative societies & Dummy variable: $(1=$ member, $0=$ otherwise $)$ & Dummy \\
\hline
\end{tabular}

introduced by the Federal Office of Statistics (2004). Monthly mean per capita household expenditure (MMPCHHE) for the sampled households was achieved by multiplying the nutrition equivalent scales with the number of fish hatchery household members with reference to age and gender categories. Two-thirds of the MAPCHHE of the sampled fish farmers was used as the poverty line value for the study. These methods have been used by several authors (Iruo et al., 2018). The model is specified as follows:

$P=\frac{2}{3} X M A P C H H E$

where:

$P=$ Poverty Line Value,

MAPCHHE = Monthly average per adult equivalent household expenditure

Adult equivalent $=1+0.7\left(\mathrm{~N}_{\text {adults }}-1\right)+0.5_{\text {children }}$

where:

$\mathrm{N}=$ Number

$P \alpha_{t}=\frac{1}{n} \sum_{i=1}^{q}\left[\frac{Z-Y_{i}}{Z}\right]^{\infty}$

where:

$P \alpha_{i}=$ poverty depth when the poverty line (Z) equals the expenditure per adult equivalent, $n=$ total number of households,

$q=$ number of households below the poverty line and $Y_{i}=$ expenditure of the household in which individual $\mathrm{i}^{\text {th }}$ lives.

\section{Tobit regression model}

Tobit regression model was used to assess determinants of poverty in the study area. This model is used because the approach can avoid the use of Pearson correlations, which are inappropriate for censored variables and instead, using correlations estimated under the assumption of a censored multivariate normal distribution (Muthen, 1989). The model also uses all the information, including those on censoring, and provides consistent estimates (Tobin 1958). Equations 9 and 10 provide an indication of how this model is fitted. The dependent variable is poverty status. The explanatory variables specified as determinants of poverty among fish farmers in the area are presented in Table 1.

$q_{i}=P_{i}=X_{i} \beta+e_{i}$, if $P_{i}>P_{i} *$

$o=X_{i} \beta+e_{i}$, if $P_{i} \leq P_{i} *$

where

$q_{i}=$ dependent variable. It is discrete when the households are not poor and continuous when they are poor.

$P_{i}=$ poverty depth intensity defined as $\left(Z-Y_{i}\right)$ and

$X_{i}=$ vector of the explanatory variable,

$\beta$ is a vector of the unknown coefficient, $e_{i}$ is an independently distributed error. 
Table 2. Distribution offish hatcheryfarmers'socio-economic characteristics

\begin{tabular}{lcc}
\hline $\begin{array}{l}\text { Socio-economic } \\
\text { characteristic }\end{array}$ & Frequency & Percentage \\
\hline Gender & 359 & 84.87 \\
\hline Male & 64 & 15.13 \\
\hline Female & & \\
\hline Age (year) & 16 & 3.78 \\
\hline $21-30$ & 63 & 14.89 \\
$31-40$ & 206 & 48.70 \\
$41-50$ & 112 & 26.48 \\
$51-60$ & 26 & 6.15 \\
61 and above & 46 & \\
\hline Mean & &
\end{tabular}

\begin{tabular}{lrr}
\hline Marital Status & & \\
\hline Single & 24 & 5.67 \\
Married & 380 & 89.83 \\
Divorced & 19 & 4.49 \\
\hline Educational level & 45 & 10.64 \\
\hline Primary & 111 & 26.24 \\
Secondary & 267 & 63.12 \\
\hline Tertiary & 94 & \\
\hline Household size (number of persons) & 22.22 \\
\hline 1-3 & 165 & 39.01 \\
4-6 & 164 & 38.77 \\
Above 6 & 7 & \\
Mean & & \\
\hline
\end{tabular}

Years of experience in fish hatchery

\begin{tabular}{lrl}
\hline $1-3$ & 105 & 24.82 \\
$4-6$ & 132 & 31.21 \\
Above 6 & 186 & 43.97 \\
Mean & 10 & \\
\hline
\end{tabular}

Membership of cooperative society

\begin{tabular}{lrl}
\hline Yes & 374 & 88.42 \\
No & 49 & 11.58 \\
\hline Number of workers/labour & & \\
\hline $1-3$ & 107 & 25.30 \\
$4-6$ & 124 & 29.31 \\
above 6 & 192 & 45.39 \\
Mean & 9 & \\
\hline Mode of operation & & \\
\hline Full time & 245 & 57.92 \\
Part time & 178 & 42.08 \\
\hline Source of water & & \\
\hline Deep well & 127 & 30.02 \\
Borehole & 296 & 69.98 \\
\hline
\end{tabular}

Source: Field Survey 2018

\section{RESULTS AND DISCUSSION}

\section{Socio-economic characteristics of respondents}

Socio-economic characteristics of the respondents are presented in Table 2 . It was observed that majority were male (84.87\%), married (89.83) and had tertiary education (63.12\%). The study revealed that both genders engaged in the enterprise intending to increase fish production and household income but males dominated. The findings of the study were in line with work of Digun-Aweto and Oladele (2017) who reported that farming activities are majorly dominated by males due to the laborious intensive nature of fish farming operations whereas females are mostly engaged in value addition. It was further observed that majority were married and this could be attributed to their level of financial commitment. The result agrees with the study of Ovwigho (2011) who opined that married individuals are saddled with numerous financial responsibilities. The study revealed that there is no illiterate among fish hatchery farmers in the study area this disagree with the general belief that fish farmers were illiterate or dropped out from a formal school system. This is in line with the findings of Digun-Aweto and Oladele (2017). Age range of 31-50 years was dominant (63.5\%). This age bracket is termed active, innovative, early adopters, motivated and energetic age range. Household size ranged from 1 to 13 persons per household with a mean household of 7 persons. Household size could be related to the role (labour) played by individuals on the farm (Amsalu and de Graaff 2007). The implication of this is that there are adequate hands to assist. Fish farmers experience ranged from 1 to 14 years, with an average of ten years' experience. Experience could be related to the number of active years spent in a particular enterprise. It is characterised with constant practice resulting in specialisation which might influence farmer's managerial ability and decision making (Ashley-Dejo et al., 2020). Labour is very important to farming activities in Nigeria because fish hatchery operation activities are carried out manually (selection of gravid fish, injection, stripping, fertilisation, siphoning, feeding and sorting). The study agreed with the finding of Agwu and Afieroho (2007) who reported that farming operation in Sub-Sahara Africa could be categorised into two: full-time and part-time. Source, quality and quantity of water are prerequisite in fish hatchery operation. Also, the quantity of water required is a function of the production method, culture medium, scale of operation and species culture. Majority (69.98\%) depend on borehole water as the main source of water. 
Table 3. Production and management system of fish hatchery farming

\begin{tabular}{lcc} 
Economic activities & Frequency & Percentage \\
\hline Number of hatchery rearing units & & \\
\hline $1-3$ & 95 & 22.46 \\
4-6 & 145 & 34.28 \\
Above 6 & 183 & 43.26 \\
Mean & 7 & \\
\hline Type of rearing facilities & & \\
\hline Wooden troughs & 44 & 10.40 \\
\hline Wooden troughs and concrete tanks & 220 & 52.01 \\
Plastic tanks & 44 & 10.40 \\
Concrete tanks & 115 & 27.19 \\
\hline Production capacity (number of fish seed produced) \\
\hline Below 3,001 & 59 & 13.95 \\
\hline 3,001-5,000 & 41 & 9.69 \\
\hline 5,001-7,000 & 96 & 22.70 \\
\hline 7,001-9,000 & 161 & 38.06 \\
\hline Above 9,000 & 66 & 15.60 \\
Mean & 8,104 & \\
\hline Average weight of male brodstock used (kg) & \\
\hline
\end{tabular}

Average weight of male broodstock used (kg)

\begin{tabular}{lrr}
\hline$\leq 1.0$ & 73 & 17.26 \\
$1.10-2.0$ & 205 & 48.46 \\
$>2.0$ & 145 & 34.28 \\
\hline
\end{tabular}

Average weight of female broodstock used (kg)

\begin{tabular}{lrl}
\hline$\leq 1.0$ & 65 & 15.37 \\
$1.1-2.0$ & 165 & 39.01 \\
$>2.0$ & 193 & 45.63 \\
\hline
\end{tabular}

Cost of male broodstock per kg (

\begin{tabular}{|c|c|c|}
\hline Less than 2,000:00 & 34 & 8.04 \\
\hline $2,000: 00-3,000: 00$ & 152 & 35.93 \\
\hline Above 3,000:00 & 237 & 56.03 \\
\hline Mean & 4,619:36 & \\
\hline \multicolumn{3}{|c|}{ Cost of female broodstock per $\mathrm{kg}$ ( } \\
\hline Less than 2,000:00 & 123 & 29.08 \\
\hline $2,000: 00-3,000: 00$ & 98 & 23.17 \\
\hline Above 3,000:00 & 202 & 47.75 \\
\hline Mean & $3,945: 34$ & \\
\hline
\end{tabular}

Types of hatchery production system used

\begin{tabular}{lcc}
\hline Flow-through & 357 & 84.40 \\
$\begin{array}{l}\text { Improvised Re-circulatory } \\
\text { Aquaculture System }\end{array}$ & 66 & 15.60 \\
\hline
\end{tabular}

Source: Field Survey 2018

\section{Production and management system of fish hatchery operation in the study area}

Table 3 reveals the production and management system of fish hatchery operation in the study area. The number of rearing units (1-16) depends on the capacity of the farm and the financial status of the farmer, which affects the production capacity. Farmers' choice of rearing facilities revealed that the majority (52.01\%) of the fish hatchery farmers uses both wooden trough and concrete tanks as their preferred choice of rearing facilities. The finding agrees with those of Omitoyin (2007) who stated that concrete tanks and wooden troughs were common in urban and pre-urban settings because of low construction cost and high durability. Majority (77.54\%) sourced for broodstocks from other fish farms to avoid inbreeding, due to no/lack of broodstock bank. The weight of broodstock (male and female) used ranged from $1.87 \mathrm{~kg}$ to $5.11 \mathrm{~kg}$ with a mean weight of $4.23 \mathrm{~kg}$ and $4.11 \mathrm{~kg}$ for male and female broodstock, respectively. This finding is in line with the data of Bui et al. (2010) who reported that the mean weight of broodstock (male and female) fish could range between 3 to $6 \mathrm{~kg}$. Majority (84.4\%) of the fish hatchery farmers used flow-through system. In Nigeria, this production system (flow-through) is very popular because it is less expensive to construct and maintain with low cost of operation.

\section{Profitability analysis of fish hatchery enterprise per annum}

The estimated profitability analysis of fish hatchery enterprise per annum is presented in Table 4. Two-thirds of the total cost of production were spent on the fixed cost which implied that fixed asset in fish hatchery enterprise was the most expensive. Fairly high net income might be related to the rate of adoption of improved fish hatchery technology which is strongly influenced by the literacy level. Benefit Cost Ratio (BCR) 1.53 was higher than one. Olagunju et al. (2007) stated that in any agribusiness with BCR greater than one is an indication that the business is profitable. Thus fish hatchery enterprise is a profitable agribusiness. Return on investment (ROI) was 0.53 which implies that a potential gain of $\$ 0.53$ for every $\$ 1.00$ invested.

\section{Poverty profile of fish hatchery farmers}

Fish hatchery farmer's poverty profile is revealed in Table 5. Standard of living of fish hatchery farmers was measured based on food and non-food items. Out of the five items considered in this study, food (38.92\%) and energy (24.16\%) had the highest percentage expenditure whereas transportation cost and social activities had the least percentage expenditure $7.58 \%$ and $7.21 \%$, 
Table 4. Profitability analysis of fish hatchery enterprise per annum

\begin{tabular}{|c|c|c|}
\hline Cost of items & Amount ( & \% Total Cost \\
\hline \multicolumn{3}{|l|}{ Fixed costs (Depreciated value) } \\
\hline Land purchase/Rent & $14,252.15$ & 9.61 \\
\hline Tanks/Troughs & $2,327.11$ & 1.57 \\
\hline Pumping machine & $9,925.99$ & 6.69 \\
\hline Water source (deep well / bore hole) & $1,4054.86$ & 9.47 \\
\hline Water reservoir (overhead tanks) & $1,937.00$ & 1.31 \\
\hline Plumbering materials & $3,099.37$ & 2.09 \\
\hline Building/shed & $5,943.51$ & 4.01 \\
\hline Tools (shovel, cutlasses) & $1,549.76$ & 1.05 \\
\hline Weighing scale & $9,035.71$ & 6.09 \\
\hline Generator & $12,713.82$ & 8.57 \\
\hline Scoop net & $1,097.42$ & 0.74 \\
\hline Permanent labour & $17,663.04$ & 11.91 \\
\hline Counting table and grader & 830.62 & 0.56 \\
\hline Wheelbarrow & $5,993.91$ & 4.04 \\
\hline Plastic spoons, pair of scissors and bowls/buckets & $1,769.84$ & 1.19 \\
\hline Total Fixed Cost (TFC) & $102,194.11$ & 68.89 \\
\hline \multicolumn{3}{|l|}{ Variable costs } \\
\hline Broodstock & $8,564.7$ & 5.77 \\
\hline Feed & $1,3491.1$ & 9.09 \\
\hline Hormone and injector (needle and syringe) & $1,735.31$ & 1.17 \\
\hline Saline water & 223.64 & 0.15 \\
\hline Fuel & $1,5359.6$ & 10.35 \\
\hline Industrial salt and drug & 595.49 & 0.40 \\
\hline Hand towels and tissue paper & 195.37 & 0.13 \\
\hline Transportation/handling charges & $2,532.17$ & 1.71 \\
\hline Kakaban, Razor and knife & 252.81 & 0.17 \\
\hline Others & $3,194.38$ & 2.15 \\
\hline Total Variable Cost (TVC) & $46,144.49$ & 31.11 \\
\hline Total Cost (TC) & $148,338.60$ & 100.00 \\
\hline Total Revenue $(T R)=(8,104 \times 28: 00$ price of fingerlings $)$ & $226,912.00$ & \\
\hline Gross Margin $(G M)=(T R-T V C)$ & $180,767.51$ & \\
\hline Net Income $(\mathrm{NI})=(\mathrm{GM}-\mathrm{TFC})$ & $78,573.44$ & \\
\hline Benefit Cost Ratio (BCR) = (TR/TC) & 1.53 & \\
\hline Return on Investment (ROI) = (NI/TC) & 0.53 & \\
\hline
\end{tabular}

Note: $\$ 1=$ 360:07 at the time of the study.

Source: Field Survey 2018

respectively. Also, MMPCHHE was 2,270.44 (\$8.73) and moderate and core poverty lines were $1,513.63$ (\$5.82) and 756.81 (\$2.91), respectively. Also, it was observed that $43.1 \%$ of fish hatchery farmers interviewed were above the poverty line and 56.9\% [moderately poor $(29.5 \%)$ and core poor $(27.4 \%)]$ were poor. Thus, the enterprise contributed greatly to household poverty alleviation in Oyo and Osun States, Southwest Nigeria. This implies that fish hatchery enterprise could be used as a tool to eradicate poverty in Nigeria. The findings of this study are in line with the work of Etuk et al. (2015) and Iruo et al. (2018) who reported that fish farming contributed towards poverty reduction in Nigeria.

\section{Determinants of poverty among fish hatchery farmers}

Determinants of poverty among fish hatchery farmers were determined using Tobit regression model. Table 6 revealed that 9 variables out of the 12 variables used in the model were significant at different probability levels. Calculated sigma $(\sigma)$ value was 0.6811 and 
Table 5. Fish hatchery framers' poverty profile

\begin{tabular}{lcr}
\hline Consumption items & $\begin{array}{c}\text { Expenditure } \\
\text { distribution (\$) }\end{array}$ & $\begin{array}{c}\text { Percentage } \\
\text { Expenditure } \\
\text { distribution }\end{array}$ \\
\hline Food & 5302.42 & 38.92 \\
Energy & 3291.06 & 24.16 \\
Outfit (clothing) & 1292.29 & 9.49 \\
Hospital bill & 1721.83 & 12.64 \\
Transportation cost & 1032.19 & 7.58 \\
Social activities & 982.83 & 7.21 \\
TOTAL & 13622.62 & 100.00 \\
Monthly mean per capita household expenditure (MMPCHHE) & $2,270.44$ & \\
Moderate poverty line 2/3 of mean & $1,513.63$ & 756.81 \\
Core poverty line 1/3 & 29.5 & \\
Moderate poverty (\%) & 27.4 & \\
Core poverty (\%) & 43.1 & \\
Non-poor (\%) & & \\
\hline Sourc: Field Survey 2018 & \\
\hline
\end{tabular}

Source: Field Survey 2018

Table 6. Determinants of poverty using maximum likelihood estimates

\begin{tabular}{lccc}
\hline Variables & Coefficient & Standard error & $t$-value \\
\hline Gender $\left(\mathbf{X}_{1}\right)$ & $-0.0316^{* * *}$ & 0.0032 & 9.514 \\
Age $\left(\mathbf{X}_{2}\right)$ & 0.4627 & 0.3363 & 1.458 \\
Marital status $\left(\mathbf{X}_{3}\right)$ & $0.0648^{*}$ & 0.0414 & 1.923 \\
Household size $\left(\mathbf{X}_{4}\right)$ & $0.1124^{*}$ & 0.0574 & 2.154 \\
Educational level $\left(\mathbf{X}_{5}\right)$ & $-0.0463^{* *}$ & 0.0314 & -2.826 \\
Farming experience $\left(\mathbf{X}_{\mathbf{6}}\right)$ & $0.4258^{* * *}$ & 0.1931 & 2.651 \\
Labour employed $\left(\mathbf{X}_{7}\right)$ & $0.2613^{* *}$ & 0.1471 & 2.946 \\
Hatchery units $\left(\mathbf{X}_{8}\right)$ & $-0.0362^{* *}$ & 0.0127 & -2.692 \\
Value of assets $\left(\mathbf{X}_{\mathbf{9}}\right)$ & 0.4714 & 0.3566 & 2.132 \\
Quantity of fish seed produced $\left(\mathbf{X}_{10}\right)$ & $-0.3413^{* *}$ & 0.2311 & -2.997 \\
Access to modern health care $\left(\mathbf{X}_{11}\right)$ & 0.3167 & 0.3661 & 1.865 \\
Membership of cooperative societies $\left(\mathbf{X}_{12}\right)$ & $-0.1114^{* *}$ & 0.1074 & -2.776 \\
Constant & $0.4135^{* *}$ & 0.1941 & 2.865 \\
Sigma $(\sigma)$ & $0.6811^{* *}$ & 0.3541 & 2.717 \\
\hline
\end{tabular}

***Significant at $1 \%, * *$ Significant at $5 \%, *$ Significant at $10 \%$ Source: Field Survey 2018

significant at 5\% probability level, which implies that the variables listed in the model were essential and of good fit with good predictive ability. The regression coefficient for gender was -0.0316 and significant at 1\% probability level. This shows that poverty depth of male fish hatchery farmers would decrease by 0.0316 resulting to increase for their female counterpart. This is due to the difference in the level of involvement (maleand female-headed household) in off-farm activities. Poverty tends to affect female-headed household more than their male counterparts. The study shows that male fish hatchery farmers are involved in other income-generating activities which provide additional revenue compared to female fish hatchery farmers. This agrees with the findings of Iruo et al. (2018) who reported a high incidence of poverty among female-headed households in Niger Delta of Nigeria.

The coefficient of education was -0.0463 . This implies that the poverty depth would decrease by 0.0463 for individuals in families whose heads had formal education to be 0.3672 . Coefficient of education was significant at $5 \%$ probability level with a negative relationship with poverty. This implies that there is an inverse relationship between education and poverty 
among fish hatchery farmers in the study area. Also, educated farmers have the tendency to adopt improved technologies which stands to raise productivity and income. The findings agree with the study of Ogundipe et al. (2019) who stated that household heads with higher educational qualification have the capacity of reducing the chances of being poor.

The coefficient (0.4258) of farming experience of fish hatchery household head revealed that there is a significant relationship between household head and poverty. A unit (year) increase in household head fish farming experience would result in 0.4258 unit increase in poverty depth. This is contrary to a priori expectation and may be explained by the fact that most experienced fish hatchery farmers in the study area operate below their production capacity which may not yield the income and profit required to bring them out of poverty (Etim et al., 2009). This denotes that experienced fish hatchery farmers' in the study area are prone to poverty. Most experienced farmers are difficult to convince on improved technologies thus living in their old system of farming which is income gulping, strenuous and labour demanding. The findings agree with the study of Oladimeji et al. (2013) and Iruo et al. (2018) who observed positive and significant relationship between fish farming experience and poverty.

It was also observed that the quantum of labour put into fish farming operations by a household was positively associated with the household's depth of poverty. The figures indicated that a man-day rise in labour employed in fish hatchery operations would raise the poverty depth by 0.2613 . This is explainable by the fact that increase in household labour usually leads to having more dependents and higher dependency ratio which tends to raise the poverty status of households. The findings agree with the study of Etim et al. (2009) and Iruo et al. (2018) who observed a positive and significant relationship between labour force and poverty.

The regression coefficient for fish hatchery unit was -0.0362 and significant at 5\% probability level. This implies that for every unit increase in fish hatchery units (rearing units) poverty level would decrease by 0.0362 . Invariably, fish hatchery unit significantly decreases poverty among fish hatchery farmers in the study area. Also, the more fish hatchery units, the lower the likelihood of being poor because there will be an increase in the number of fish seed produced; more fingerlings to sell which in turn increase farmers revenue and standard of living. The regression coefficient for the value of fish seed produced was -0.03413 and significant at 5\% probability level which implies that an increase in fish seed produced would decrease fish hatchery farmers' poverty level by 0.03413. The regression coefficient of membership of cooperative societies was -0.1114 and significant at $5 \%$ probability level. This finding agrees with a priori expectation that members of cooperative societies have access to first-hand information on improved technologies, updated information on price, input and improved technologies thus improving farmers' welfare.

\section{CONCLUSION}

The study examined the economics of catfish fish hatchery farmers and its contribution to household poverty alleviation in Oyo and Osun States, Southwest Nigeria. Profitability analyses, Foster-Greer-Thorbecke index and Tobit regression model were used to achieve the set objectives. From the empirical evidence arising from this finding, it was revealed that fish hatchery enterprise is worth investing in; it is very profitable and it is neither gender- nor age-biased although it requires little capital for fixed cost which could gulp about $70 \%$ of total cost of production and contribute greatly to household poverty alleviation in Oyo and Osun States, Southwest Nigeria. Thus, there is a need to educate fish hatchery farmers to embrace re-circulatory production system to boost fish seed production which will help in alleviating poverty on the long run. The study reveals that poverty among fish hatchery farmers is driven by different factors such as gender, marital status, household size, educational level, fish hatchery experience, labour employed, hatchery units, the quantity of fish seed produced and membership of a cooperative society. Fish hatchery production significantly reduced poverty in farmer's households in the study area.

Also, government and non-governmental institutions in collaboration with universities or research institutes should encourage fish hatchery farmers either by organising empowerment programme, or provision of some of the fixed assets such as land, drilling of a borehole, establishing broodstock bank or gene bank, etc. This will motivate young and old, educated and illiterate to venture into fish breeding business thereby boosting the country's fish productivity, creating employment and eradicate poverty.

\section{CONFLICT OF INTEREST}

The authors declared no conflicts of interest with respect to research, authorship and publication of this article. 


\section{ETHICAL COMPLIANCE}

The authors have followed the ethical standards in conducting the research and preparing the manuscript.

\section{REFERENCES}

Adelaja O. A., Kamaruddin R. B., Chiat L. W. (2018): Assessment of post-harvest fish losses Croaker Pseudotolithus elongatus, (Bowdich, 1825), Catfish Arius heudeloti, (Valenciennes, 1840) and Shrimp Nematopala emonhastatus (Aurivillius, 1898) in Ondo State, Nigeria. Aquaculture and Fisheries 3: 209-216.

Agwu A. E., Afieroho E. O. (2007): Influence of personal and institution factors on adoption of improved pond management practices among fish farmers in Isoko Local Government Area, Delta State. Nigeria Journal Animal Production 34: 121-131.

Amsalu A., de Graaff J. (2007): Determinants of adoption and continued use of stone terraces for soil and water conservation in an Ethiopian highland watershed. Ecological Economics 61: 294-302.

Ashley-Dejo S. S., Adelaja O. A., Idi-Ogede A. M. (2020): Factors Influencing Fishermen's Perception on Climate Change and Choice of Coping Strategies in Ondo State, Nigeria. Agricultural Economics and Extension Research Studies 8: 119-126.

Ashley-Dejo S. S., Olaoye O. J., Adelaja O. A. (2017): Analysis of profitability of small-scale catfish farmers in Oyo State, Nigeria. Malaysian Journal of Animal Science 20: 11-24.

Ashley-Dejo S. S. (2016): Adoption of improved hatchery production technologies of Clarias gariepinu (Burchell, 1822) among fish farmers in Oyo and Osun States, Nigeria. Ph. D. Thesis University of Agriculture, Abeokuta, Nigeria, 210 p.

Bolorunduro P. I. (2016): Fisheries extension service in Nigeria: the good, the bad, the ugly and the way forward. Inaugural lecture, Department of Livestock and Fisheries, National Agricultural Extension Research Liaison Service, Ahmadu Bello University, Zaria, 74 p.

Boltvinik J. (1994): Poverty Measurement and Indicators of Development. In: van der Hoeven, R. and Anker, R. (Eds.), Poverty Monitoring: An International Concern, UNICEF, 1994. https:// dx.doi.org/10.1007/978-1-349-23134-8_4.

Bui T. M., Phan L. T., Ingram B. A., Nguyen T. T. T., Gooley G. J., Nguyen H. V. (2010): Seed production practices of stripped catfish, Pangasian odonhypophthalamus in the Mekong Delta region, Vietnam. Aquaculture 306: 92-100.

Digun-Aweto O., Oladele A. H. (2017): Awareness of Improved Hatchery Management Practices among
Fish Farmers in Lagos State. Agricultura Tropica et Subtropica 50: 19-25.

Etim N. A. A., Patrick I. V. (2010): Estimating the Determinants of Poverty among Fishing Households in Akwa Ibom State, Nigeria. Journal of Agriculture and Social Sciences 6: 61-63.

Etim N. A., Edet G. E., Esu B. B. (2009): Determinants of Poverty among Peri-urban Telferia occidentals Farmers in Uyo, Nigeria. Journal of Agriculture and Social Sciences 5: 49-51.

Etuk E., Angba C., Angba A. (2015): Determinants of Poverty Status of Fish Vendor Households in Lower Cross River Basin, Nigeria. Journal of Economics and Sustainable Development 6: 50-55.

Federal Office of Statistics (FOS) (2004): Nigeria Living Standard Survey 2003/2004. Report prepared by FOS in collaboration with EU, World Bank, Department for International Studies.

Food and Agricultural Organization (FAO) (2018): State of World Fisheries and Aquaculture: Meeting the sustainable development goals. Food and Agriculture Organization of the United Nations, $227 \mathrm{p}$.

Food and Agriculture Organization (FAO) (2020): The State of World Fisheries and Aquaculture. Sustainability in action. Rome 224 p. https://doi. org/10.4060/ca9229en.

Foster J., Greer J., Thorbecke E. (1984): A Class of Decomposable Poverty Measures. Econometrica 52: 761-765. https://dx.doi.org/10.2307/1913475.

Igbalajobi O., Fatuase A. I., Ajibefun I. (2013): Determinants of Poverty Incidence among Rural Farmers in Ondo State, Nigeria. American Journal of Rural Development 1: 131-137.

Inoni O. E., Ogisi O. D, Achoja F. O. (2017): Profitability and Technical Efficiency in Homestead Catfish Production in Delta State, Nigeria. Economics of Agriculture 64: 1449-1465. UDC: 338.31(639.21:597.551.4).

Iruo F. A., Onyeneke R. U., Eze C. C., Uwadoka C., Igberi C. O. (2018): Economics of Smallholder Fish Farming to Poverty Alleviation in the Niger Delta Region of Nigeria. Turkish Journal of Fisheries and Aquatic Sciences19: 313-329. http://doi.org/10.4194/13032712-v19_4_06.

Lipton M. (1996): Defining and Measuring Poverty: Conceptual Issues, Background Paper for HDR97, UNDP, New York, 1996.

Muthen B. O. (1989): Tobit Factor Analysis. British Journal of Mathematical and Statistical Psychology 42: 241-250. https://dx.doi. org/10.1111/j.2044-8317.1989.tb00913.x 
National Agricultural Extension and Research Liaison Services and National Programme on Agriculture and Food Security (NAERLS and NPAFS) (2010): Annual agricultural performance survey report of Nigeria 2010 Wet Season. NAERLS Press. 153 p. ISBN: 978-978-912-360-5.

Ndamu R. K. (2016): Fish Farming Enterprises and Poverty Reduction in Adamawa State, Nigeria. Journal of Resources Development and Management 21: 53-59.

Ogundipe A. A., Ogunniyi A., Olagunju K., Asaleye A. J. (2019): Poverty and Income Inequality in Rural Agrarian Household of Southwestern Nigeria: The Gender Perspective. The Open Agriculture Journal 13: 51-57. DOI: 10.2174/1874331501913010051.

Oladimeji Y. U., Abdulsalam Z., Damisa M. A., Omokorem D. F. (2013): Estimating the Determinants of Poverty among Artisanal Fishing Households in Edu and Moro Local Government Areas of Kwara State, Nigeria. Agriculture and Biology Journal of North America 4: 422-429. https://dx.doi. org/10.5251/abjna.2013.4.4.422.429.

Olagunju F. I., Adesiyan I. O., Ezekiel A. A. (2007): Economic viability of catfish production in Oyo-State, Nigeria Journal of Human Ecology 21: 121-124.

Oluwatayo I. B., Adedeji T. A. (2019): Comparative analysis of technical efficiency of catfish farms using different technologies in Lagos State, Nigeria: a Data Envelopment Analysis (DEA) approach. Journal of Agriculture \& Food Security 8: 1-9. https://doi. org/10.1186/s40066-019-0252-2.
Omitoyin B. O. (2007): Introduction to fish farming in Nigeria. Ibadan University Press, Publishing House, University of Ibadan, Ibadan, Nigeria, pp. 1-87.

Ovwigho B. O. (2011): Construction of Socioeconomic Status Scale for Heads of Rural Farm Families in the Central Agricultural Zone of Delta State, Nigeria. Extension Farming Systems Journal 7: 21-28.

Ravallion M. (1992): Poverty Comparisons: A Guide to Concepts and Methods. World Bank LSMS Working Paper No. 88.

Ravallion M., Sen B. (1994): Impact on Rural Poverty of Land Based Target: Further Results for Bangladesh. World Bank Development 22: 823-838.

Sidi O. (2008): Poverty Reduction Through Sustainable Agricultural and Enterprises Development in Nigeria. In Akinyemiju, A. O. and Torimiro, D. O. (Eds): Agricultural Extension. A Comprehensive Treatise with Model Questions and Glossary. ABC Agricultural Systems Ltd, Ikeja, Lagos, Nigeria.

Tesfay S., Teferi M. (2017): Assessment of fish post-harvest losses in Tekeze dam and Lake Hashenge fishery associations: northern Ethiopia. Agriculture \& Food Security 6: 45-51.

Tobin J. (1958): Estimation of Relationships for Limited Dependent Variables. Econometrica 26: 24-36. https://dx.doi.org/10.2307/1907382.

World Bank (1996): Nigeria Poverty in the midst of Plenty: The Challenges of Growth with Inclusion. A World Bank Poverty Assessment. Population and Human Resource Division. West Africa Department, African Region Reported No. 14733.

Received: November 25, 2020 Accepted after revisions: February 5, 2022 